\title{
Pengaruh Dosis Jamur Pelarut Fosfat Aspergillus niger dan Pupuk Kandang Ayam Terhadap Pertumbuhan dan Hasil Tanaman Kubis bunga (Brassica oleracea var. botrytis L.)
}

\section{Dose effect of phosphate solvent fungus Aspergillus niger and Chicken Manure on Growth and Yield of Cauliflower (Brassica oleracea var. botrytis, L).}

\author{
Desti Sona Anggareni $^{1,}$ Jenal Mutakin $^{1}$, Siti Syarah Maesyaroh ${ }^{1}$ \\ Program Studi Agroteknologi Fakultas Pertanian Universitas Garut \\ Jalan Raya Samarang No. 52 A Tarogong Kidul Kabupaten Garut 44151 \\ e-mail : jenalmutakin@uniga.ac.id
}

\begin{abstract}
ABSTRAK
Penelitian ini bertujuan untuk mengetahui dosis jamur pelarut fosfat Aspergillus niger dan pupuk kandang ayam yang dapat memberikan pengaruh terbaik terhadap pertumbuhan dan hasil tanaman kubis bunga. Penelitian dilakukan di Desa Sukahurip Kecamatan Cigedug Kabupaten Garut pada Bulan Mei sampai Juli 2019. Penelitian menggunkan Rancangan Acak Kelompok (RAK) faktorial 4 $\times 4$ dengan 2 ulangan. Faktor pertama adalah dosis jamur pelarut fosfat Aspergillus niger (J) dengan 4 taraf, yaitu : kontrol, $10 \mathrm{ml} / \operatorname{tanaman}, 20$ $\mathrm{ml} /$ tanaman, dan $30 \mathrm{ml} /$ tanaman. Faktor ke dua adalah dosis pupuk kandang ayam (P) dengan 4 taraf, yaitu : kontrol, 10 ton/ha, 20 ton/ha, dan 30 ton/ha. Hasil penelitian menunjukkan tidak terjadi interaksi antara pemberian jamur pelarut fosfat Aspergillus niger dan pupuk kandang ayam terhadap pertumbuhan dan hasil tanamanan kubis bunga. Secara mandiri jamur pelarut fosfat Aspergillus niger dengan dosis $20 \mathrm{ml} /$ tanaman $\left(\mathrm{j}_{2}\right)$ dapat meningkatkan nilai bobot kering tanaman. Dosis pupuk kandang ayam 20 ton/ha $\left(\mathrm{p}_{2}\right)$ memberikan pengaruh terbaik terhadap tinggi tanaman, jumlah daun dan bobot kering tanaman.
\end{abstract}

Kata kunci : Kubis Bunga, Jamur Pelarut Fosfat Aspergillus niger, Pupuk Kandang Ayam.

\section{ABSTRACT}

This research was aimed to know the dosage of phosphate solubilizing fungi Aspergillus niger and chicken manure that can give the best effect on growth and yield of cauliflower. The research was conducted in Sukahurip Village, Subdistrict of Cigedug, Garut from May to July 2019. This research was conducted using Randomized Design $4 \times 4$ factorial with two replications. First factor is the dosage of phosphate solubilizing fungi Aspergillus niger $(J)$ with four level, is : control, $10 \mathrm{ml} / \mathrm{plant}, 20 \mathrm{ml} / \mathrm{plant}$, and $30 \mathrm{ml} / \mathrm{plant}$. Second factor is the dosage of chicken manure $(P)$ with four level, is : control, 10 ton/ha, 20 ton/ha, and 30 ton/ha. The result showed no interaction occureed between phosphate solubilizing fungi Aspergillus niger addition and chicken manure on growth and yield of cauliflower. Independently phosphate solubilizing fungi Aspergillus niger with 20 
$\mathrm{ml} / \mathrm{crop}\left(\mathrm{j}_{2}\right)$ dosage can increased the plant dry weight value. Dosage of chicken manure 20 ton/ha $\left(p_{2}\right)$ give the best effect for plant height, number of leaves, and plant dry weight.

Keywords : Cauliflower, Phosphate Solubilizing Fungi Aspergillus niger, Chicken Manure.

\section{PENDAHULUAN}

Kubis bunga atau sering juga disebut sebagai kembang kol (Brassica oleracea var. botritys L.) merupakan tanaman sayuran famili Brassicaceae jenis kol dengan bunga putih, berupa tumbuhan berbatang lunak yang berasal dari Eropa. Kubis bunga merupakan salah satu komoditas sayuran yang banyak dikonsumsi di Indonesia. Bertambahnya jumlah penduduk akan meningkatkan jumlah kebutuhan pangan sayuran, termasuk kubis bunga (Cahyono, 2001).Kubis bunga merupakan jenis sayuran yang mempunyai peranan penting untuk kesehatan karena kubis bunga mengandung mineral dan vitamin yang dibutuhkan tubuh manusia. Mineral yang terkandung dalam kubis bunga antara lain adalah kalsium, besi, fosfor, dan sulfat, sedangkan vitamin yang terkandung antara lain adalah vitamin A, vitamin B, dan vitamin C (Cahyono, 2001).

Peluang pasar kubis bunga terbuka lebar seiring dengan meningkatnya permintaan akan konsumsi kubis bunga. Permintaan kubis bunga yang meningkat harus diikuti dengan peningkatan produksi agar kebutuhan konsumen dapat terpenuhi. Salah satu faktor yang mempengaruhi suatu tanaman yaitu produktivitas tanaman itu sendiri. Produktivitas kubis bunga di Indonesia mengalami fluktuasi dari tahun 2012 sampai 2016 yaitu berturut-turut sebesar 11,54 ton/ha, 12,18 ton/ha, 12,08 ton/ha dan 11,91 ton/ha (Berdasarkan BPS dan Dirjen Hortikultura, 2017). Produksi kubis bunga di Indonesia pada tahun 2017 mencapai 152.869 ton. Produktivitas tanaman salah satunya dapat ditingkatkan dengan memperbaiki sifat fisik, biologi, dan kimia tanah sebagai tempat tumbuh tanaman.

Aspergillus niger sebagai jamur pelarut fosfat. Fosfat merupakan nutrient essensial yang diperlukan oleh tanaman dalam proses pertumbuhan dan perkembangannya. Jumlah fosfat di dalam tanah melimpah sekitar 95-99\% 
terdapat dalam bentuk fosfat tidak terlarut sehingga tidak dapat digunakan oleh tanaman (Raharjo dkk., 2007). Jamur pelarut fosfat mempunyai peranan penting dalam kemampuan melepaskan ikatan $\mathrm{P}$ dan berperan dalam melarutkan $\mathrm{P}$ yang tidak tersedia menjadi $\mathrm{P}$ tersedia. Upaya yang dapat dilakukan untuk meningkatkan ketersediaan $\mathrm{P}$ di dalam tanah antara lain dengan penambahan pupuk organik.

Pupuk kandang ayam merupakan salah satu pupuk organik yang dapat diaplikasikan untuk meningkatkan efisiensi penyerapan fosfat oleh tanaman. Pupuk organik ini mengandung unsur hara makro dan mikro yang cukup lengkap, meskipun kandungan fosfatnya sedikit. Pupuk ini memiliki kandungan nitrogen yang lebih banyak dibandingkan dengan pupuk organik lain.

\section{METODE PENELITIAN}

Penelitian dilaksanakan di Desa Sukahurip, Kecamatan Cigedug, Kabupaten Garut. Ketinggian tempat 1.200 meter di atas permukaan laut (mdpl). Tipe curah hujan berdasarkan kriteria Schmidt and Ferguson (1951) adalah tipe curah hujan B. Tekstur tanah di lokasi percobaan adalah lempung berdebu dengan pH 7,20. Penelitian dilaksanakan pada Bulan Mei sampai Juli 2019

Bahan yang digunakan dalam penelitian ini meliputi benih kubis bunga varietas Aquina F1, pupuk kandang ayam, Jamur pelarut fosfat Aspergilus niger (Asal Laboratorium Unpad). Alat yang digunakan adalah cangkul, kored, tugal, gembor, ember, timbangan, tali rapia, bambu, gelas ukur, oven, amplop, pisau, label, keranjang, papan nama, meteran, mistar, kalkulator, kamera dan alat tulis.

Metode yang digunakan dalam penelitian ini adalah eksperimental dengan menggunakan Rancangan Acak Kelompok (RAK) Pola Faktorial $4 \times 4$ diulang sebanyak dua kali. Faktor pertama adalah jamur pelarut fosfat (J) terdiri atas empat taraf, yaitu: $\mathrm{j}_{0}$ : Kontrol, $\mathrm{j}_{1}: 10 \mathrm{ml} / \operatorname{tanaman}, \mathrm{j}_{2}: 20 \mathrm{ml} / \operatorname{tanaman}, \mathrm{j}_{3}: 30$ $\mathrm{ml} /$ tanaman. Faktor kedua adalah pupuk kandang ayam (P) yang terdiri empat taraf, yaitu: $\mathrm{p}_{0}:$ Kontrol, $\mathrm{p}_{1}: 10$ ton/ha setara $6,2 \mathrm{~kg} / \mathrm{plot}, \mathrm{p}_{2}: 20$ ton/ha setara 12,5 $\mathrm{kg} / \mathrm{plot}, \mathrm{p}_{3}: 30$ ton/ha setara 18,7 kg/plot. Terdapat 16 kombinasi taraf perlakuan percobaan yang diulang sebanyak dua kali sehingga terdapat 32 plot percobaan. Ukuran plot percobaan adalah $250 \mathrm{~cm} \times 200 \mathrm{~cm}$, setiap plot terdiri atas 20 
tanaman, dengan total dari keseluruhan tanaman adalah 640 tanaman dengan jarak tanam $50 \mathrm{~cm} \times 50 \mathrm{~cm}$ dan jarak antar ulangan yaitu $50 \mathrm{~cm}$.

Komponen pengamatan yang dilakukan adalah Tinggi Tanaman (cm), Jumlah Daun (helai), Luas Daun $\left(\mathrm{cm}^{2}\right)$, Bobot Kering per Tanaman (g), Diameter Bunga per Tanaman (cm), Bobot Bunga per Tanaman (g) dan Bobot Bunga per Plot (g). Analisis data dari hasil penelitian dilakukan berdasarkan model linear menurut Gomes dan Gomes (1995). Untuk mengetahui tingkat perbedaan masing-masing perlakuan, maka dilakukan uji $\mathrm{F}$ dengan kaidah pengambilan keputusan. Apabila $F_{\text {hit }}$ lebih besar dari $F_{\text {tab }}$ maka dilakukan uji lanjutan dengan menggunakan uji jarak berganda duncan (Duncan Multiple Range Test).

\section{HASIL DAN PEMBAHASAN}

\section{Tinggi Tanaman (cm)}

Analisis ragam statistik tinggi tanaman dapat dilihat pada Lampiran 6, 7, 8, 9. Hasil analisis ragam menunjukkan bahwa tidak terjadi interaksi antara pemberian dosis jamur pelarut fosfat dan pupuk kandang ayam terhadap tinggi tanaman, namun secara mandiri menunjukkan pengaruhnya masing-masing, hasil analisis dapat dilihat pada Tabel 3.

Tabel 3. Rata-rata Tinggi Tanaman (cm)

\begin{tabular}{|c|c|c|c|c|}
\hline \multirow{2}{*}{ Perlakuan } & \multicolumn{4}{|c|}{ Tinggi Tanaman (cm) } \\
\hline & $14 \mathrm{HST}$ & $21 \mathrm{HST}$ & $28 \mathrm{HST}$ & $35 \mathrm{HST}$ \\
\hline \multicolumn{5}{|l|}{ Jamur Pelarut Fosfat $(\mathrm{J})$} \\
\hline $\mathrm{j}_{0}$ (Kontrol) & 21,18 a & 26,36 a & 32,15 a & 37,59 a \\
\hline $\mathrm{j}_{1}(10 \mathrm{ml} /$ tanaman $)$ & 22,06 a & 28,35 a & 33,99 a & $40,14 \mathrm{a}$ \\
\hline $\mathrm{j}_{2}(20 \mathrm{ml} /$ tanaman $)$ & $22,25 \mathrm{a}$ & $27,55 \mathrm{a}$ & $32,67 \mathrm{a}$ & 38,41 a \\
\hline $\mathrm{j}_{3}(30 \mathrm{ml} /$ tanaman $)$ & $20,61 \mathrm{a}$ & 26,48 a & 32,81 a & 38,01 a \\
\hline \multicolumn{5}{|l|}{ Pupuk Kandang Ayam (P) } \\
\hline $\mathrm{p}_{0}$ (kontrol) & 18,70 a & 24,18 a & 30,51 a & 35,58 a \\
\hline $\mathrm{p}_{1}(10$ ton/ha $)$ & $21,31 \mathrm{~b}$ & $27,20 \mathrm{~b}$ & 32,38 a & $38,26 \mathrm{a}$ \\
\hline $\mathrm{p}_{2}(20$ ton ha) & $23,02 \mathrm{~b}$ & $29,53 \mathrm{~b}$ & $\begin{array}{c}36,20 \\
\text { b }\end{array}$ & $42,26 \mathrm{~b}$ \\
\hline $\mathrm{p}_{3}(30$ ton/ha) & $23,07 \mathrm{~b}$ & $27,84 \mathrm{~b}$ & 32,55 a & 38,05 a \\
\hline
\end{tabular}

Keterangan : Angka rata-rata pada kolom yang ditandai dengan huruf yang sama menunjukkan tidak berbeda nyata menurut Uji Jarak Berganda Duncan pada taraf 5\% 
Hasil analisis sidik ragam pada berbagai taraf perlakuan jamur pelarut fosfat pada umur 14, 21, 28, dan 35 HST terlihat tidak berbeda nyata, sedangkan Pengaruh mandiri pada berbagai taraf perlakuan pupuk kandang ayam pada umur 14 dan 21 HST terlihat berbeda nyata, taraf perlakuan $\mathrm{p}_{0}$ terlihat berbeda nyata dengan $\mathrm{p}_{1}, \mathrm{p}_{2}$, dan $\mathrm{p}_{3}$. Taraf perlakuan pupuk kandang ayam pada umur 28 dan 35 HST terlihat berbeda nyata, taraf $\mathrm{p}_{0}, \mathrm{p}_{1}, \mathrm{p}_{3}$ berbeda nyata dengan $\mathrm{p}_{2}$.

Hal ini diduga karena jamur pelarut fosfat dapat memacu pertumbuhan tanaman yang erat kaitannya dengan sifat genetik dan kandungan unsur hara. Suplai sebagian unsur hara yang dibutuhkan tanaman dapat dilakukan oleh jamur pelarut fosfat yang dapat merubah unsur $\mathrm{P}$ di dalam tanah menjadi P-tersedia bagi pertumbuhan tanaman, sehingga dapat menghemat penggunaan pupuk kimia, sedangkan pupuk kandang ayam mengandung unsur hara yang dibutuhkan oleh tanaman untuk pertumbuhan maupun perkembangannya. Sutedjo (2002) menyatakan bahwa pupuk kandang ayam merupakan pupuk yang lengkap karena selain dapat menimbulkan tersediannya unsur hara bagi tanaman, pupuk kandang ayam juga dapat mengembangkan mikroorganisme (jasad renik) di dalam tanah yang dapat mempengaruhi sifat fisik tanah.

\section{Jumlah Daun (helai)}

Hasil analisis statistik jumlah daun dapat dilihat pada Lampiran 10, 11, 12, 13. Hasil analisis ragam menunjukkan bahwa tidak terjadi interaksi antara pemberian dosis jamur pelarut fosfat dan pupuk kandang ayam terhadap jumlah daun tanaman kubis bunga, namun secara mandiri menunjukkan pengaruh msingmasing terhadap jumlah daun kubis bunga, hasil analisis dapat dilihat pada Tabel 4.

Hasil analisis sidik ragam pada berbagai taraf perlakuan jamur pelarut fosfat pada umur 14, 21, 28, dan 35 HST terlihat tidak berbeda nyata, namun pada setiap pengamatan menunjukkan peningkatan pertumbuhan pada jumlah daun. Penambahan jumlah daun merupakan pertumbuhan vegetatif, Hal ini diduga dosis yang diberikan tidak efektif untuk pertumbuhan jumlah daun, kemungkinan jumlah dosis yang diberikan tidak dapat meyerap fosfat dengan baik. Menurut Ginting (2006) menyatakan bahwa pertumbuhan mikroorganisme pelarut fosfat 
sangat dipengaruhi oleh kemasaman tanah, pada tanah masam aktivitas mikroorganisme didomisili oleh kelompok jamur sebab pertumbuhan jamur yang optimum pada ph 5-5,5. Pertumbuhan fungi menurun dengan meningkatnya $\mathrm{pH}$. Hal ini terjadi karena keadaan tanah yang netral dilapangan sehingga jamur tidak tumbuh optimal.

Tabel 4. Rata-rata Jumlah Daun (helai)

\begin{tabular}{|c|c|c|c|c|}
\hline \multirow{2}{*}{ Perlakuan } & \multicolumn{4}{|c|}{ Rata-rata Jumlah Daun (Helai) } \\
\hline & $14 \mathrm{HST}$ & $21 \mathrm{HST}$ & $28 \mathrm{HST}$ & $35 \mathrm{HST}$ \\
\hline \multicolumn{5}{|l|}{ Jamur Pelarut Fosfat $(\mathrm{J})$} \\
\hline $\mathrm{j}_{0}$ (Kontrol) & 5,78 a & 6,80 a & 8,78 a & $10,20 \mathrm{a}$ \\
\hline $\mathrm{j}_{1}(10 \mathrm{ml} /$ tanaman $)$ & $5,90 \mathrm{a}$ & 6,83 a & 8,73 a & $9,90 \quad \mathrm{a}$ \\
\hline $\mathrm{j}_{2}(20 \mathrm{ml} /$ tanaman $)$ & $6,30 \mathrm{a}$ & 7,13 a & 8,83 a & $10,00 \mathrm{a}$ \\
\hline $\mathrm{j}_{3}(30 \mathrm{ml} /$ tanaman $)$ & $5,90 \mathrm{a}$ & 6,90 a & 8,73 a & $9,88 \quad \mathrm{a}$ \\
\hline \multicolumn{5}{|c|}{ Pupuk Kandang Ayam (P) } \\
\hline $\mathrm{p}_{0}$ (kontrol) & $5,58 \mathrm{a}$ & 6,18 a & 8,08 a & 9,13 a \\
\hline $\mathrm{p}_{1}(10$ ton/ha $)$ & 5,63 a & $7,25 \mathrm{ab}$ & $8,50 \mathrm{ab}$ & 9,85 al \\
\hline $\mathrm{p}_{2}(20$ ton/ha $)$ & $6,35 \mathrm{~b}$ & $6,75 \mathrm{~b}$ & $9,53 \mathrm{c}$ & $10,63 \mathrm{~b}$ \\
\hline $\mathrm{p}_{3}(30$ ton/ha) & $6,33 \mathrm{~b}$ & $7,48 \mathrm{~b}$ & $8,95 \mathrm{bc}$ & $10,38 \mathrm{~b}$ \\
\hline
\end{tabular}

Keterangan : Angka rata-rata pada kolom yang ditandai dengan huruf yang sama menunjukkan tidak berbeda nyata menurut Uji Jarak Berganda Duncan pada taraf 5\%.

Hasil analisis ragam pada berbagai taraf perlakuan pupuk kandang ayam terlihat berbeda nyata pada umur 14 HST taraf faktor $\mathrm{p}_{0}$ dan $\mathrm{p}_{1}$ berbeda nyata dengan taraf faktor $\mathrm{p}_{2}$ dan $\mathrm{p}_{3}$, pada umur $21 \mathrm{HST}$ faktor $\mathrm{p}_{0}$ berbeda sangat nyata dengan taraf faktor $\mathrm{p}_{2}$ dan $\mathrm{p}_{3}$ namun tidak berbeda nyata dengan faktor lainnya. Rata-rata jumlah daun pada 28 HST menunjukkan bakwa faktor $\mathrm{p}_{0}$ berbeda sangat nyata dengan taraf $\mathrm{p}_{2}$ namun tidak berbeda nyata dengan taraf lainnya, sedangkan pada umur 35 HST menunjukkan bahwa taraf $\mathrm{p}_{0}$ berbeda nyata dengan taraf $\mathrm{p}_{2}$ dan $\mathrm{p}_{3}$ namun tidak berbeda nyata dengan taraf lainnya. Dilihat dari angka ratarata tertinggi terhadap luas daun ditunjukkan pada taraf faktor $\mathrm{p}_{2}=20$ ton/ha

Menurut Hasan (2002) adanya unsur nitrogen akan meningkatkan petumbuhan bagian vegetatif seperti daun. Hal ini sesuai dengan pendapat Lingga dan Marsono (2008) bahwa peranan utama nitrogen bagi tanaman adalah untuk merangsang pertumbuhan secara keseluruhan khususnya batang, cabang dan daun. 
Seperti dikemukakan oleh Rosmarkam (2001) bahwa pupuk ayam yang dicampur dengan tanah semakin lama diinkubasikan akan mengalami dekomposisi dan mampu menyediakan unsur hara bagi tanaman.

\section{Luas Daun $\left(\mathrm{cm}^{2}\right)$}

Hasil analisis statistik luas daun tanaman dapat dilihat pada Lampiran 14. Analisis ragam menunjukkan bahwa tidak terjadi interaksi antara pemberian dosis jamur pelarut fosfat dan pupuk kandang ayam terhadap luas daun tanaman kubis bunga, dan secara mandiri tidak memberikan pengaruh yang nyata terhadap luas daun kubis bunga. Hasil analisis dapat dilihat pada Tabel 5 rata-rata semua faktor perlakuan tidak memberikan pengaruh yang nyata bagi peningkatan luas daun.

Tabel 5. Rata-rata Luas Daun $\left(\mathrm{cm}^{2}\right)$

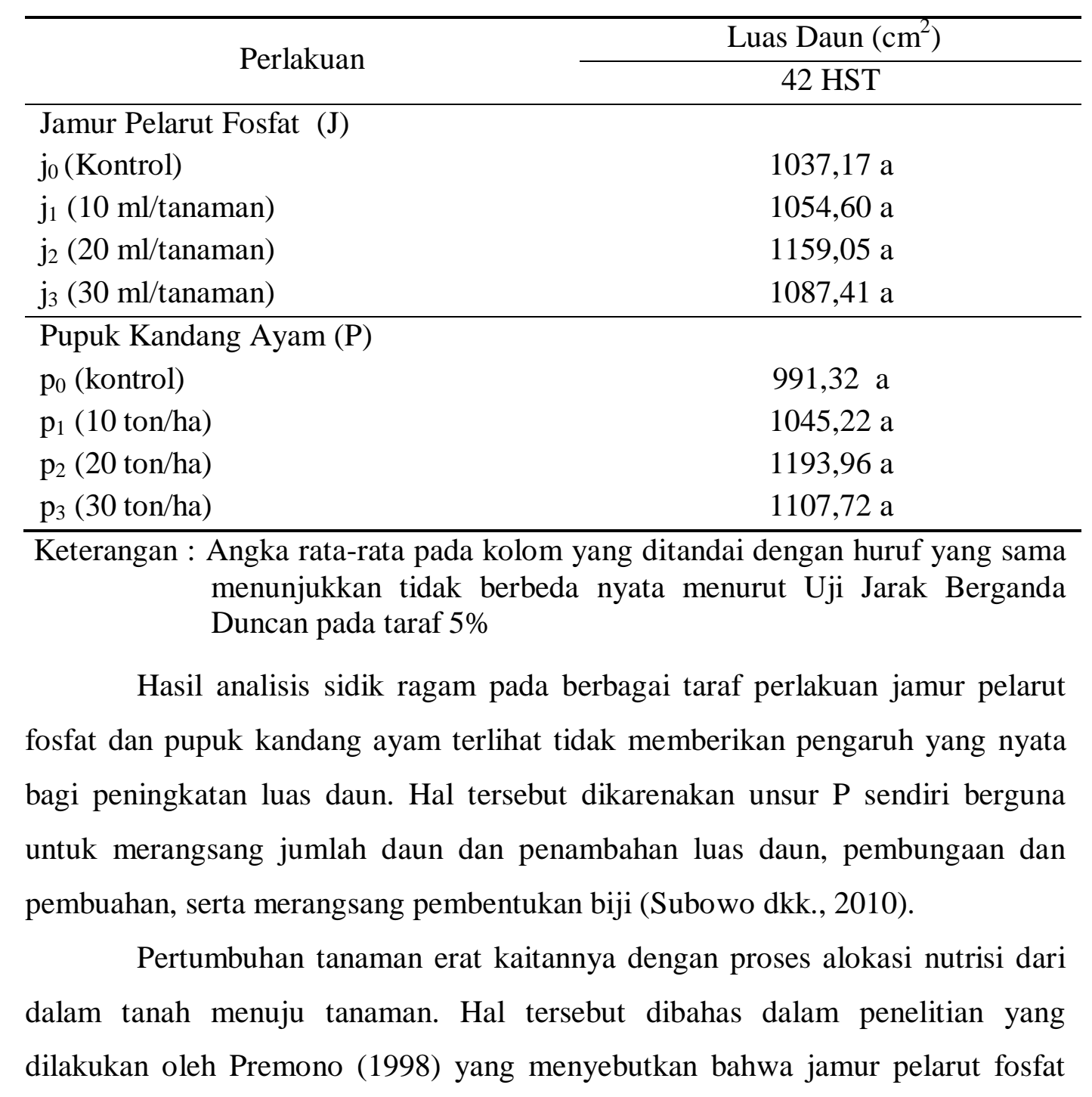


memiliki 3 mekanisme dalam meningkatkan penyerapan P yaitu : (1) secara fisik, dimana infeksi jamur pada akar tanaman dapat membantu pengambilan fosfat dengan memperluas permukaan sampai akar ; (2) secara kimia, jamur diduga mendorong perubahan $\mathrm{pH}$ perakaran. Jamur juga menghasilkan asam sitrat dan asam oksalat yang menggantikan posisi ion fosfat yang terfiksasi ; (3) secara fisiologis, jamur menghasilkan hormon auksin, sitokinin dan giberelin yang dapat memperlambat proses penuaan akar sehingga memperpanjang masa penyerapan unsur hara.

Pupuk kandang ayam dapat dimanfaatkan untuk meningkatkan konsentrasi hara dalam tanah. Selain itu, pupuk kandang ayam juga dapat memperbaiki tata udara dan air tanah, dengan demikian perakaran tanaman akan berkembang dengan baik dan akar dapat menyerap unsur hara yang lebih banyak, terutama unsur hara $\mathrm{N}$ yang akan meningkatkan pembentukan klorofil, sehingga aktivitas fotosintesis lebih meningkat dan dapat meningkatkan luas daun.

\section{Bobot Kering Tanaman (g)}

Hasil analisis statistik bobot kering tanaman dapat dilihat pada Lampiran 15. Analisis ragam menunjukkan bahwa tidak terjadi interaksi antara pemberian dosis jamur pelarut fosfat dan pupuk kandang ayam terhadap bobot kering tanaman kubis bunga, namun secara mandiri menunjukkan pengaruh masingmasing terhadap bobot kering tanaman kubis bunga, hasil analisis dapat dilihat pada Tabel 6.

Tabel 6. Rata-rata Bobot Kering Tanaman (g)

Perlakuan

Bobot Kering Tanaman(g)

\begin{tabular}{lcl}
\hline Jamur Pelarut Fosfat $(\mathrm{J})$ & 7,04 & $\mathrm{a}$ \\
$\mathrm{j}_{0}($ Kontrol $)$ & 9,53 & $\mathrm{ab}$ \\
$\mathrm{j}_{1}(10 \mathrm{ml} /$ tanaman $)$ & 12,18 & $\mathrm{~b}$ \\
$\mathrm{j}_{2}(20 \mathrm{ml} /$ tanaman$)$ & 11,29 & $\mathrm{~b}$ \\
$\mathrm{j}_{3}(30 \mathrm{ml} /$ tanaman$)$ & & \\
\hline Pupuk Kandang Ayam (P) & $6,59 \mathrm{a}$ \\
$\mathrm{p}_{0}($ kontrol) & $10,38 \mathrm{~b}$ \\
$\mathrm{p}_{1}(10$ ton/ha) & $11,29 \mathrm{~b}$ \\
$\mathrm{p}_{2}(20$ ton/ha) & $11,78 \mathrm{~b}$ \\
$\mathrm{p}_{3}(30$ ton/ha) & & \\
\hline
\end{tabular}


Keterangan : Angka rata-rata pada kolom yang ditandai dengan huruf yang sama menunjukkan tidak berbeda nyata menurut Uji Jarak Berganda Duncan pada taraf 5\%

Taraf perlakuan $\mathrm{j}_{2}$ dan $\mathrm{j}_{3}$ menghasilkan berat kering tertinggi dibanding taraf perlakuan lainnya. Hal ini diduga jamur pelarut fosfat pada taraf tersebut memberikan kecepatan penguraian hara tidak tersedia menjadi tersedia yang lebih cepat dibanding perlakuan lainnya. Jamur pelarut fosfat pada perakaran tanaman memberikan pengaruh baik, inokulan tersebut meningkatkan ketahanan pada tanaman dan mampu bertahan hidup (Waty, 2012). Taraf $\mathrm{j}_{2}$ menjadi taraf yang efisien karena dengan dosis yang lebih rendah menghasilkan bobot kering yang berbeda nyata dibanding $\mathrm{j}_{0}$.

Taraf perlakuan $\mathrm{p}_{1}, \mathrm{p}_{2}$ dan $\mathrm{p}_{3}$ memiliki hasil analisis ragam tertinggi dibanding taraf perlakuan lainnya, namun penggunaan pupuk kandang ayam pada taraf $\mathrm{p}_{2}$ menjadikan yang paling efisien karena dengan dosis yang lebih rendah menghasilkan bobot kering yang berbeda nyata disbanding $\mathrm{p}_{1}$. Bobot kering merupakan akibat dari penimbunan hasil asimilasi $\mathrm{CO}_{2}$ sepanjang musim pertumbuhan, asimilasi $\mathrm{CO}_{2}$ merupakan hasil penyerapan energi matahari dan akibat radiasi matahari. Faktor utama yang mempengaruhi bobot kering total adalah radiasi matahari yang diabsorbsi dan efesiensi pemanfaatan energi tersebut untuk fiksasi $\mathrm{CO}_{2}$ (Gardner dkk., 1991).

Peningkatan dosis pupuk kandang ayam selalu diikuti oleh peningkatan bobot kering tanaman yang semakin tinggi, hal ini disebabkan pupuk kandang ayam yang dibenamkan ke dalam tanah telah terdekomposisi dan juga meningkatnya bobot kering tanaman. Peningkatan bobot kering tanaman membuktikan bahwa tumbuh kembangnya tanaman semakin baik dengan adanya pemberian bahan organik. Bahan organik merupakan sumber unsur hara $\mathrm{N}, \mathrm{P}$ dan $\mathrm{K}$ bagi tanaman, dengan demikian meningkatnya bahan organik akan meningkatkan ketersediaan unsur-unsur tersebut bagi tanaman (Wahyudi, 2009).

\section{Diameter Bunga per Tanaman (g)}

Hasil analisis statistik diameter bunga per tanaman dapat dilihat pada Lampiran 16. Analisis ragam menunjukkan bahwa tidak terjadi interaksi antara pemberian dosis jamur pelarut fosfat dan pupuk kandang ayam terhadap diameter 
bunga per tanaman, dan secara mandiri juga tidak memberikan pengaruh yang nyata terhadap diameter bunga per tanaman pada kubis bunga pada 45 hari setelah tanam (HST), hasil analisis diameter bunga per tanaman dapat dilihat pada Tabel 7.

Unsur hara fosfat yang diserap tanaman berada dalam bentuk terikat dengan molekul-molekul lainnya dalam tumbuhan. Unsur fosfat yang terikat pada lipid membentuk fosfolipid yang merupakan bagian dari membran plasma tumbuhan (Campbell dkk., 2000). Ketersediaan fosfat di alam dibatasi oleh banyaknya unsur tersebut yang menyatu membentuk persenyawaan dengan unsurunsur lain (Schachtman dkk., 1998). Sebanyak lebih dari 80\% unsur fosfat yang dimasukkan kedalam tanah dalam kegiatan pemupukan terjadi tidak mobil atau hanya kurang dari 10\% yang masuk ke dalam siklus tanaman (Panhwar dkk., 2011).

Tabel 7. Rata-rata Diameter Bunga per Tanaman (g)

$$
\text { Perlakuan Diameter Bunga }(\mathrm{cm})
$$

\begin{tabular}{ll}
\hline Jamur Pelarut Fosfat $(\mathrm{J})$ & \\
$\mathrm{j}_{0}$ (Kontrol) & $15,58 \mathrm{a}$ \\
$\mathrm{j}_{1}(10 \mathrm{ml} /$ tanaman $)$ & $18,60 \mathrm{a}$ \\
$\mathrm{j}_{2}(20 \mathrm{ml} /$ tanaman $)$ & $17,28 \mathrm{a}$ \\
$\mathrm{j}_{3}(30 \mathrm{ml} /$ tanaman $)$ & $17,10 \mathrm{a}$ \\
\hline Pupuk Kandang Ayam $(\mathrm{P})$ & \\
$\mathrm{p}_{0}$ (kontrol) & $16,75 \mathrm{a}$ \\
$\mathrm{p}_{1}(10$ ton/ha) & $17,33 \mathrm{a}$ \\
$\mathrm{p}_{2}(20$ ton/ha) & $17,05 \mathrm{a}$ \\
$\mathrm{p}_{3}(30$ ton/ha) & $17,43 \mathrm{a}$
\end{tabular}

Keterangan : Angka rata-rata pada kolom yang ditandai dengan huruf yang sama menunjukkan tidak berbeda nyata menurut Uji Jarak Berganda Duncan pada taraf 5\%

Ketersediaan dan keseimbangan komposisi nutrisi dan energi pada media tanaman. Pupuk kandang ayam memiliki tekstur yang halus dan mudah terdekomposisi dengan cepat sehingga tanaman mudah dan cepat untuk menyerap unsur hara. Sesuai dengan pernyataan Widowati dkk. (2004) bahwa lamaya proses dekomposisi pada pupuk kandang dipengaruhi tekstur pupuk itu sendiri. Tekstur yang berbentuk butiran-butiran dan padat agak sukar pecah secara fisik sehingga 
lambat terdekomposisi dan ketersediaan unsur hara tidak dapat diserap tanaman sehingga menyebabkan lamanya pertumbuhan pada tanaman.

Curd kubis bunga merupakan perkembangan generatif yang erat kaitannya dengan pupuk kalium. Menurut Jones dkk. (1991) kalium merupakan unsur makro yang terlibat dalam mempertahankan status air tanaman dan pembukaan dan penutupan stomata. Unsur kalium pada hasil analisis tanah sebelum penelitian pada Lampiran 1 yang menyatakan kriteria sedang, memberikan kecukupan hara kalium untuk diserap tanaman.

\section{Bobot Bunga per Tanaman (g)}

Hasil analisis statistik bobot bunga per tanaman dapat dilihat pada Lampiran 17. Analisis ragam menunjukkan bahwa tidak terjadi interaksi antara pemberian dosis jamur pelarut fosfat dan pupuk kandang ayam terhadap bobot bunga per tanaman, dan secara mandiri juga tidak memberikan pengaruh yang nyata terhadap bobot bunga per tanaman, hasil analisis dapat dilihat pada Tabel 8 . Jamur pelarut fosfat jenis Aspergillus niger merupakan jamur yang mampu mengurai bahan organik yang terkandung di dalam tanah. Analisis tanah pada Lampiran 2 tentang analisis tanah sebelum penelitian menunjukkan kandungan pupuk kalium yang sedang sehingga dengan adanya bantuan jamur pelarut fosfat, pupuk kalium bisa diurai menjadi bentuk yang sederhana dan menjadi tersedia bagi tanaman.

Tabel 8. Rata-rata Bobot Bunga per Tanaman $(\mathrm{g})$

Perlakuan

Bobot Bunga Per Tanaman

(g)

\begin{tabular}{ll}
\hline Jamur Pelarut Fosfat $(\mathrm{J})$ & $366,65 \mathrm{a}$ \\
$\mathrm{j}_{0}($ Kontrol$)$ & $415,98 \mathrm{a}$ \\
$\mathrm{j}_{1}(10 \mathrm{ml} /$ tanaman $)$ & $382,75 \mathrm{a}$ \\
$\mathrm{j}_{2}(20 \mathrm{ml} /$ tanaman $)$ & $369,88 \mathrm{a}$ \\
$\mathrm{j}_{3}(30 \mathrm{ml} /$ tanaman $)$ & \\
\hline Pupuk Kandang Ayam $(\mathrm{P})$ & $370,75 \mathrm{a}$ \\
$\mathrm{p}_{0}($ kontrol $)$ & $384,65 \mathrm{a}$ \\
$\mathrm{p}_{1}(10$ ton/ha) & $393,88 \mathrm{a}$ \\
$\mathrm{p}_{2}(20$ ton/ha) & $385,98 \mathrm{a}$ \\
$\mathrm{p}_{3}(30$ ton/ha) & \\
\hline
\end{tabular}


Keterangan : Angka rata-rata pada kolom yang ditandai dengan huruf yang sama menunjukkan tidak berbeda nyata menurut Uji Jarak Berganda Duncan pada taraf 5\%

Pertumbuhan generatif erat kaitannya dengan pupuk kalium yang biasa menambah bobot (curd) kubis bunga. Diduga pemberian dosis 20 ton/ha adalah dosis yang efektif dalam penyediaan unsur kalium bagi tanaman kubis bunga pada percobaan penelitian. Sesuai dengan penelitian Baroto (2007) yang menyimpulkan bahwa pemberian pupuk kandang ayam 20 ton/ha mampu meningkatkan jumlah daun, luas daun, dan komponen produksi yang meliputi berat segar total tanaman, berat basah krop, diameter krop, dan bobot segar krop tanaman kubis bunga.

\section{Bobot Bunga per Plot (g)}

Hasil analisis statistik bobot bunga per plot dapat dilihat pada Lampiran 18. Analisis ragam menunjukkan bahwa tidak terjadi interaksi antara pemberian dosis jamur pelarut fosfat dan pupuk kandang ayam terhadap bobot bunga per plot, dan secara mandiri juga tidak memberikan pengaruh yang nyata terhadap bobot bunga per plot, hasil analisis dapat dilihat pada Tabel 9.

Tabel 9. Rata-rata Bobot Bunga per Plot (g)

\begin{tabular}{lc}
\hline \multicolumn{1}{c}{ Perlakuan } & Bobot Bunga Per Plot $(\mathrm{g})$ \\
\hline Jamur Pelarut Fosfat $(\mathrm{J})$ & \\
$\mathrm{j}_{0}($ Kontrol $)$ & $4924,38 \mathrm{a}$ \\
$\mathrm{j}_{1}(10 \mathrm{ml} /$ tanaman $)$ & $5578,13 \mathrm{a}$ \\
$\mathrm{j}_{2}(20 \mathrm{ml} /$ tanaman $)$ & $5591,88 \mathrm{a}$ \\
$\mathrm{j}_{3}(30 \mathrm{ml} /$ tanaman $)$ & $5141,88 \mathrm{a}$ \\
\hline Pupuk Kandang Ayam $(\mathrm{P})$ & \\
$\mathrm{p}_{0}$ (kontrol) & $5008,13 \mathrm{a}$ \\
$\mathrm{p}_{1}(10$ ton/ha) & $5696,88 \mathrm{a}$ \\
$\mathrm{p}_{2}(20$ ton/ha) & $5475,00 \mathrm{a}$ \\
$\mathrm{p}_{3}(30$ ton/ha) & $5056,25 \mathrm{a}$ \\
\hline
\end{tabular}

Keterangan : Angka rata-rata pada kolom yang ditandai dengan huruf yang sama menunjukkan tidak berbeda nyata menurut Uji Jarak Berganda Duncan pada taraf 5\%

Semua taraf faktor perlakuan tidak memberikan pengaruh secara mandiri dikarenakan penggunaan jamur pelarut fosfat tidak efektif terhadap bobot bunga per plot kemungkinan karena dosis yang kurang tinggi, terjadi penguapan dan 
terjadi kesenjangan jamur antara tanaman satu dengan yang lainya, akibatnya fosfat di dalam tanah tidak terserap oleh tanaman.

Pengaruh mandiri perlakuan pupuk kandang ayam juga tidak memberikan pengaruh secara signifikan karena penambahan bahan organik dari pupuk kandang ayam tidak efektif dengan dosis tersebut bisa karena terjadi penguapan yang mengakibatkan tidak signifikannya terhadap perlakuan hasil bobot kubis bunga, dan juga dapat dipengaruhi oleh bunga yang berbeda pada setiap plot percobaan. Pemenuhan kebutuhan unsur hara pada media tanam (tanah) di lingkungan penanaman akan membantu hasil produksi lebih tinggi dibandingkan dengan tanah yang kekurangan nutrisi bagi tanaman. Nurhidayati dkk. (2008) menyatakan, penambahan unsur hara dan bahan organik dapat memperbaiki struktur tanah menjadi lebih remah sehingga memudahkan akar tanaman menyerap unsur hara dari dalam tanah.

\section{KESIMPULAN}

Berdasarkan hasil penelitian mengenai pengaruh dosis jamur pelarut fosfat Aspergillus niger dan pupuk kandang ayam terhadap pertumbuhan dan hasil tanaman kubis bunga dapat disimpulkan sebagai berikut :

1. Tidak terjadi interaksi antara berbagai berbagai dosis jamur pelarut fosfat dan pupuk kandang ayam terhadap pertumbuhan dan hasil kubis bunga.

2. Secara mandiri pemberian jamur pelarut fosfat dengan dosis $20 \mathrm{ml} /$ tanaman $\left(\mathrm{j}_{2}\right)$ dapat meningkatkan nilai terbaik terhadap bobot kering tanaman, sedangkan pemberian dosis pupuk kandang ayam 20 ton/ha $\left(\mathrm{p}_{2}\right)$ memberikan pengaruh terbaik terhadap tinggi tanaman, jumlah daun dan bobot kering tanaman.

\section{DAFTAR PUSTAKA}

Badan Pusat Statistika dan Direktorat Jendral Hortikultura. 2017. Produktivitas Sayuran di Indonesia, 2012-2016. www.pertanian.go.id. Diakses tanggal 25 Februari 2019.

Baroto, B. A. 2007. Pengaruh Dosis Pupuk Kandang Ayam dan Jarak Tanam Terhadap Pertumbuhan dan Hasil Tanaman Kubis Bunga (Brassica oleracea). Skripsi. Fakultas Pertanian Universitas Muhammadiyah Malang, Malang.

Cahyono, B. 2001. Kubis Bunga dan Broccoli. Kanisius, Yogyakarta. 
Campbell. 2002. Biologi. Jilid III. Erlangga, Jakarta.

Gardner FP, Pearce RB, and Mitchell RL. 1991. Fisiologi Tanaman Budidaya. Universitas Indonesia, Jakarta.

Ginting, R. C. B., R. Saraswati, E. Husen. 2006. Pupuk Organik dan Pupuk Hayati. Balai Besar Penelitian dan Pengembangan Sumberdaya Lahan Pertanian. Bogor.

Hasan basri jumin. 2002. Agroekologi: Suatu Pendekatan Fisiologis. Rajawali Press, Jakarta. 179 hal.

Jones, Jr. JB., B. Wolf., and H. A. Mills. 1991. Plant Analysis Handbook. MacroMicro Publishing, Inc. Georgia.

Lingga P dan Marsono. 2008. Petunjuk Penggunaan Pupuk. Penebar Swadaya, Bandung.

Nurhidayati, Istirochah, P., Anis, S., Djuhari, dan Basit, A. 2008. Pertanian Organik Suatu Kajian Sistem Pertanian Terpadu dan Berkelanjutan. Universitas Islam Malang. Malang.

Panhwar, Q.A., Radziah, O., Zaharah, A. R., Sariah, M., Razi, I. M. 2011. Role of Phosphate Solubilizing Bacteria on Rock Phosphate Solubility and Growth of Aerobic Rice. J Environ Biol, 32: 607-612

Premono, E. M. 1998. Ulas Balik: Mikroba Pelarut Fosfat untuk Mengefisienkan Pupuk Fosfat dan Prospeknya di Indonesia. Journal of Hayati 5(4):89-94.

Raharjo, B., Agung, S., Agustina, D. K. 2007. Pelarutan Fosfat Anorganik oleh Kultur Campur Jamur Pelarut Fosfat secara In Vitro. Jurnal Sains \& Matematika (JSM), Vol. 15(2).

Rosmarkam, A. 2001. Ilmu Kesuburan Tanah. Jurusan Tanah. Fakultas Pertanian. Universitas Gadjah Mada, Yogyakarta. 210 hal

Schatchman, D. P., R. J. Roberts, and S, M. Ayling. 1998. Phsphorus Uptake by Plants : from soil to cell. Plant Physiology, 116: $447-453$.

Schmidt, F.H dan Ferguson, J.H.A. 1951. Rainfall Types Based on Wet and Dry Period Ration for Indonesia With Western Guinea. Kementrian Perhubungan Meteorologi dan Geofisika, Jakarta

Subowo, Mulyadi S., Widodo, dan Asep Nugraha, 2010. Status dan Penyebaran $P b, C d$, dan Pestisida pada Lahan Sawah Intensifikasi di Pinggir Jalan Raya. Prosiding. Bidang Kimia dan Bioteknologi Tanah, Puslittanak, Bogor. 
Sutedjo, M. M. 2002. Penerapan Pertanian Organik. Kanisius, Jakarta. 31 hlm

Wahyudi, I. 2009. Serapan N Tanaman Jagung (zea mays L.) Akibat Pemberian Pupuk Guano dan Pupuk Hijau Lamtoro pada Ultisol Wanga. J. Agroland $16(4): 265-272$

Waty, Rahmah. 2012. Potensi Aspergillus niger dan Penicillium sp Sebagai Endosimbion Pelarut Fosfat Pada Akar Serelia. Departemen Biologi Fakultas Matematika dan Ilmu Pengetahuan Alam Institut Pertanian Bogor. Bogor.

Widowati. L. R., Sri Widati, U. Jaenudin, W. Hartatik. 2004. Pengaruh Pupuk Kompos Organik yang Diperkaya dengan Bahan Mineral dan Pupuk Hayati Terhadap Sifat-sifat Tanah, Serapan Hara dan Produksi Sayuran Organik. Laporan Proyek Penelitian Program Pengembangan Agribisnis Balai Penelitian Tanah. Bogor 